\title{
JOSÉ BONIFÁCIO "O MOÇO"
}

\author{
Antonio Junqueira de Azevedo \\ Professor Titular do Departamento de Direito Civil \\ da Faculdade de Direito da USP \\ Diretor da Faculdade de Direito da Universidade de São Paulo
}

José Bonifácio nasceu em 1827, no mesmo ano de fundação da Faculdade de Direito.

Nasceu em Bordeaux, França, por ocasião do exilio de seu pai, Martim Francisco. Sua mãe, Gabriela Frederica, era sobrinha do marido; casaram-se em 1820, ela com 14 anos e Martim Francisco, com 45. Gabriela Frederica era filha do José Bonifácio da Independência e, por conseguinte, José Bonifácio "o Moço" era, ao mesmo tempo, sobrinho e neto d' "o Velho".

Bom estudante, poeta, professor benquisto pelos alunos, grande orador parlamentar, José Bonifácio morreu no auge da campanha abolicionista, em 1886, pouco antes de completar 59 anos. Sua morte, inesperada, causou grande comoção em São Paulo e no Rio. Joaquim Nabuco falou em "catástrofe nacional", Machado de Assis dedicou uma poesia ao "portentoso Andrada", Rui Barbosa se referiu à morte do "libertador".

Seu corpo foi levado da Praça da Sé ao Cemitério da Consolação, por 20 mil pessoas, no maior enterro que São Paulo já viu.

Quatro anos depois, era inaugurada a estátua que hoje se encontra no saguão da Faculdade, materializando, assim, para sempre, o que ele foi: uma espécie de "santo" da Casa.

Vejamos sua atividade de poeta, profesšor, orador parlamentar e líder abolicionista.

\section{O POETA}

Logo após sua morte, generalizou-se a impressão de que José Bonifácio teria sido grande orador parlamentar, mas poeta menor. Se, de fato, não se ombreia com a trindade romântica cujos nomes estão gravados nos pórticos da Faculdade, Fagundes Varela, Álvares de Azevedo e Castro Alves, 
nem por isso é possível deixar de reconhecer que José Bonifácio escreveu algumas poesias notáveis. $\mathrm{O}$ valor dessas poesias foi reconhecido posteriormente até mesmo por críticos acerbos como Sívio Romero e João Ribeiro (Compêndio de história da literatura brasileira, p. 516).

Em 1848, publicou Rosas e goivos, de inspiração ultraromântica, à moda de seu companheiro de Faculdade, Álvares de Azevedo; são poesias em que o tema da morte e da sepultura aparecem continuamente. Na própria apresentação do livro (dita Duas palavras), rosas e goivos são flores, mas caem sobre a lousa do túmulo que esmaga a vida. Exemplo típico dessa inspiração fúnebre é a poesia em que a moça tuberculosa, "a tísica", dança, perde as forças e morre.

"E a orquestra soa - pelo ar se expande

Em mágico vozeio o som da música,

$E$ a voz dos ecos repercute ao longe

E no vasto salão doideja a dança.

E ela valsa! Descuidosa e louca

Não vê a sepultura;

Cansado arfa seu peito, e a fronte cai-lhe

Tão cheia de amargura!

Febril delírio lhe estremece o corpo,

Passa-lhe a voz quebrada;

E sempre valsa em turbilhöes envolta

E quase desmaiada! ...

E valsa, e valsa! - Fraca e abatida

Que fôrça inda a sustenta?

Mas já na infausta lida a pobre tísica

Não pode - desalenta.

E após riso infernal ... dêsse mistério

Rompeu-se o negro véu; 
E por terra caiu, já não respira,

Vive, mas é no céu."

De Manuel Antonio Álvares de Azevedo se diz que nasceu, viveu e morreu na Faculdade. Conta a tradição que Álvares de Azevedo teria nascido na biblioteca da Faculdade; sua mãe, Maria Luiza Silveira da Mota, filha do desembargador Silveira da Mota, que morava na esquina da rua da Cruz Preta (hoje Quintino Bocaiúva) com a rua da Freira (hoje Senador Feijó), vinha muito à Escola, onde estudavam então (1831), na mesma turma, terceiranistas, tanto seu marido, Ignácio Manuel Álvares de Azevedo, quanto seu irmão, José Ignácio Silveira da Mota, futuro professor da Casa. Já nos últimos dias da gravidez, Maria Luiza teria vindo à Faculdade para assistir a alguma cerimônia, quando sentiu as dores do parto e foi carregada às pressas para a biblioteca. A história corresponde à imagem de "filho da Academia" que Álvares de Azevedo depois tomou; cumpre, porém, dizer que estudos mais recentes de professores dedicados à vida da Faculdade duvidam da veracidade da história, optando por colocar o nascimento do poeta em uma biblioteca, mas a de seu avô, desembargador, no imóvel acima referido.

Tendo o "poeta da Academia" morrido sem se formar, após completar o quarto ano, dedicou-lhe José Bonifácio, no mesmo ano da morte, 1852, versos chorosos. Diz:

"O sol apenas nasceu; peregrino, porque parou teu passo

fatigado? Não é doce a manhã??"

E termina:

"Inda a mata reluz, a tarde é longe,

E tu não voltas, oh, meu caro amigo!

Oh! quando, à noite, creio ouvir-te o passo ...

Vai-se sumindo ao longe... embalde o sigo!"

Apesar da freqüente inspiração fúnebre, algumas vezes, tal e qual o amigo, José Bonifácio fez poesias facetas, com um quê de humor popular. Ao contrário, porém, de Álvares de Azevedo que não é sensual nem mesmo nesse tipo de poesia Mário de Andrade chegou a sustentar que Álvares de Azevedo 
teria um desajuste sexual porque todas as mulheres de sua obra ou são psicologicamente assexuadas (a mãe, a irmã, as virgens de poucos anos, a adormecida a que não se deve acordar) ou são prostitutas e, portanto, ou "intangiveis ou despreziveis" em José Bonifácio, pelo menos, alguma malícia se nota. Por exemplo, na poesia dedicada a essa parte erótica do corpo humano, que é o pé.

"Adorem outros palpitantes seios,

Seios de neve pura;

De angélico sorrir meiga fragrância;

Ou sôbre o colo de nevada garça,

Caindo a mêdo, em ondas aloiradas,

Bastos anéis de tranças perfumadas;

Adorem outros de um airoso porte

Relevados contornos,

A majestade da beleza altiva,

Desdenhoso passo, o gesto ousado,

A descuidosa mão, que a trança alisa

$\mathrm{Na}$ trípode infernal a pitonisa.

Não, não quero painéis de tal encanto,

Tenho gostos humildes.

Amo espreitar a negligente perna

Que mal se esconde nas rendadas saias,

Ou ver subindo o patamar da escada

Sem asas, a voar, um pé de fada!

Um pé, como eu já vi, de tez mimosa,

De tez fôlha de rosa,

Leve, esguio, pequeno, carinhoso,

Apertado, a gemer, num sapatinho;

Um pé de matar gente e pisar flores,

Namorado da lua e pai de amôres! 
Um pé, como eu já vi, subindo a escada

Da casa de um doutor;

Da moçoila gentil, erguida a saia,

Deixou-me ver a delicada perna.

Padres, não me negueis, se estais em calma,

Um coração no pé, na perna uma alma."

E termina, com humor inglês, supondo que morto, no túmulo, com a marca do pé da amada gravada na laje, possa, a partir desse pé, imaginar o "resto" do corpo desejado:

"Poeta do amor e da saudade,

Depois de morto peço,

Em vez de cruz, sôbre a funérea pedra,

A forma do seu pé: foi o meu culto...

Quero sonhar o resto, enquanto a lua,

Chorosa e triste, pelo céu flutua ..."

Um tema fundamental do romantismo brasileiro foi, como se sabe, $o$ indianismo. A visão idealizada do índio, aliás, produz efeitos até hoje, tal a quantidade de estudos e tal a atenção que merece o índio. Infelizmente, tenho para mim que essa dedicação intelectual ao índio veio em detrimento do elemento negro na composição da alma brasileira. $O$ indianismo prevaleceu sobre o africanismo e 1850, sob esse aspecto, foi um ano crucial. Nesse ano, Gonçalves Dias publicou o excepcional Y Juca Pirama; neste notável poema, um jovem índio tupi, saindo à procura de alimentos e deixando o velho pai, já cego, na mata, é preso pelos Timbiras e diz:

"Meu canto de morte

Guerreiros, ouvi:

Sou filho das selvas,

Nas selvas cresci;

Guerreiro, descendo

Da tribu tupi. 
Da tribu pujante,

Que agora anda errante

Por fado inconstante,

Guerreiro, nasci:

Sou bravo, sou forte,

Sou filho do norte;

Meu canto de morte,

Guerreiros, ouvi.

Andei longes terras,

Lidei cruas guerras,

Vaguei pelas serras

Dos vis Aimorés;

$V i$ lutas de bravos,

Vi fortes-escravos!

De estranhos ignavos

Calcados aos pés.

Ao velho coitado

De penas ralado,

Já cego e quebrado,

Que resta? - Morrer.

Em quanto descreve

$O$ giro tão breve

Da vida que teve,

Deixai-me viver!

Não vil, não ignavo,

Mas forte, mas bravo,

Serei vosso escravo:

Aqui virei ter.

Guerreiros, não córo

Do pranto que choro, 
Se a vida deploro,

Também sei morrer."

Ora, no mesmo ano de 1850, José Bonifácio, quase sob idêntico ritmo, escrevendo Saudades do escravo, a respeito de um negro escravizado que sonha com a liberdade de Palmares, praticamente inicia a presença do africanismo na poesia brasileira. A poesia de José Bonifácio é muito menos extensa que o poema de Gonçalves Dias mas tem acentos parecidos.

"Escravo - não, não morri

Nos ferros da escravidão;

Lá nos palmares vivi,

Tenho livre o coração!

Nas minhas carnes rasgadas,

Nas faces ensanguentadas

Sinto as torturas de cá;

Dêste corpo desgraçado

Meu espirito soltado

Não partiu - ficou-me lá!...

Naquelas quentes areias,

Naquela terra de fogo,

Onde livre de cadeias

Eu corria em desafôgo...

Lá nos confins do horizonte...

Lá nas planícies... nos montes...

Lá nas alturas do céu...

De sôbre a mata florida

Esta minha alma perdida

Não veio - só parti eu.

A liberdade que eu tive

Por escravo não perdi-a;

Minha alma que lá só vive

Tornou-me a face sombria. 
O zunir do fero açoite

Por estas sombras da noite

Nāo chega, não, aos palmares!...

Lá tenho terras e flores...

Minha mãe... os meus amôres...

Nuvens e céus... os meus lares!...

Escravo não, inda vivo,

Inda espero a morte ali;

Sou livre, embora cativo,

Sou livre, inda não morri!

Meu coração bate ainda

Nesse bater que não finda;

Sou homem - Deus o dirá!

Dêste corpo desgraçado

Meu espírito soltado

Não partiu - ficou-me lá."

Duas das mais conhecidas poesias da literatura brasileira, Meus oito anos, de Casimiro de Abreu, e Visita à casa paterna, de Luiz Guimarães Júnior especialmente esta têm inspiração em poesias de José Bonifácio (Desejos e Soneto). Comparemos alguns versos de Casimiro de Abreu com os de José Bonifácio, escritos dez anos antes (1857 e 1848, respectivamente). Diz o nosso poeta, sobre os tempos da infância:

"Quem me dera ser criança

Reviver tempo de outrora,

Não ter males como agora,

Ver no futuro uma aurora,

E no presente a esperança!

Quem me dera as travessuras

Da minha quadra passada, 
E a carreira tresloucada,
E a vida tão esmaltada
De tanto amor e doçuras!"

E o poeta fluminense de forma semelhante:

"Ohl que saudades que tenho

Da aurora da minha vida

Da minha infância querida

Que os anos não trazem mais!

Que amor, que sonhos, que flôres,

$N$ 'aquelas tardes fagueiras

A'sombra das bananeiras,

Debaixo dos laranjais!"

Ou, ainda, José Bonifácio:

"Quem me dera os contozinhos,

Que minha mãe me contava,

As orações que eu rezava,

Que o velho pai me ensinava,

E seu afago e carinhos."

E Casimiro de Abreu:

"Em vez das mágoas de agora,

Eu tinha n'essas delícias

De minha māe as carícias

E beijos de minha irmã!

Rezava as Ave-Marias,

Achava o céu sempre lindo,

Adormecia sorrindo

E despertava a cantar!" 
E, finalmente, José Bonifácio:

"Oh! que delícia tivera!

Não conhecer outra idade,

Não saber o que é maldade,

Gozar sempre a felicidade...

Senhor! Senhor! Quem me dera!"

Casimiro de Abreu:

"Oh! dias da minha infância!

Oh! meu céu de primavera!

Que doce a vida não era

N'essa risonha manhã!

Que amor, que sonhos, que flôres,

$N$ 'aquelas tardes fagueiras

$A$ ' sombra das bananeiras,

Debaixo dos laranjais!"

Ainda que se reconheça a superioridade da poesia posterior, parece evidente seu débito para com a de José Bonifácio. O mesmo se diga da Visita à casa paterna de Luiz Guimarães.

José Bonifácio começa assim o seu soneto:

"Deserta a casa está... Entrei chorando,

De quarto em quarto, em busca de ilusões!

Por tôda a parte as pálidas visões!

Por tôda a parte as lágrimas falando!

Vejo meu pai na sala, caminhando,

Da luz da tarde aos tépidos clarões,

De minha mãe escuto as oraçôes

Na alcova, aonde ajoelhei rezando. 
Brincam minhas irmãs (doce lembrança!...),

Na sala de jantar... Ai! mocidade,

És tão veloz, e o tempo não descansa!"

E Luiz Guimarães, após a conhecidíssima primeira estrofe, escreve:

"Entrei. Um genio carinhoso e amigo,

O fantasma, talvez, do amor materno

Tomou-me as mãos, - olhou-me grave e terno,

E passo a passo, caminhou comigo.

Era esta a sala... (Oh! se me lembro! e quanto!)

Em que da luz noturna à claridade,

Minhas irmãs e minha māe... O pranto

Jorrou-me em ondas..."

José Bonifácio termina:

"Oh! sonhos, sonhos meus de claridade!

Como é tardia a última esperança!...

Meu Deus, como é tamanha esta saudade!..."

E Luiz Guimarães:

"... O pranto

Jorrou-me em ondas... Resistir quem ha de?

Uma ilusão gemia em cada canto,

Chorava em cada canto uma saudade..."

Para finalizar a exposição de sua atividade de poeta, lembremos duas poesias num gênero em que José Bonifácio foi excelente, o patriótico. A primeira, $O$ redivivo, foi escrita em homenagem ao general Andrade Neves, o Barão do Triunfo, tendo sido recitada no Brasil inteiro, ao final da Guerra do Paraguai. Andrade Neves, já com 61 anos, havia realizado uma das mais brilhantes cargas de cavalaria da Guerra, a de Avaí, em 11 de dezembro de 1868. Logo em seguida, o exército brasileiro travava o combate de Lamas Valentinas, cuja vitória permitiu a entrada do exército nacional em Assumpção. Andrade Neves, porém, ferido no pé, tomado pela febre, veio a falecer em janeiro de 
1869, no Palácio Velho de Solano Lopez - "a pátria além", como diz o poema de José Bonifácio. Delirando, o grande general de cavalaria ordenava ainda: "Camaradas, mais uma carga, mais uma carga!". A poesia começa assim:

"Dorme o batalhador!... por que chorá-lo?

Armas em funeral - silêncio, ó bravos!

Que a dor näo o desperte!

Tão só... tão grande... sôbre a terra inerte!

A pátria além... partido o coração...

Saudade imensa e imensa solidāo!...

Não o despertem! - êle dorme agora

Embalado nos braços da metralha.

Ao trom da artilharia;

Por lençol - a bandeira, em terra fria;

Tem por leito - os troféus; por travesseiro

Tem o canhão no sono derradeiro!

Sorrindo adormeceu a espada em punho! -

A imaginar sonhando, ouvir no espaço

O clarim da investida!

A cabeceira - a morte agradecida;

Aos pés - a glória; e ao lado ajoelhada

A pátria, pobre mãe desventurada!"

E termina:

'Armas em continência! É um morto vivo!

Ei-lo que passa agora, erguido ao alto

No esquife da vitória!

O Brasil te saúda, e tu, História,

Um poema de luz de nôvo escreves!

Soldados, cortejai Andrade Neves!" 
A última poesia que gostaria de lembrar também diz respeito à Guerra do Paraguai. O homenageado, aqui, foi o "soldado 42" do corpo de voluntários paulistas, um corneteiro negro, de quem se disse que, mesmo tendo perdido um braço, continuou a tocar o "Avança!", segurando a corneta com o braço que lhe restava. $O$ corneteiro chamava-se Jesus.

"Toca, toca, avança, avança!

São horas de combater;

Sāo horas, ninguém descansa,

Ninguém... vencer ou morrer!

Por tôda a parte a peleja,

Feia, convulsa, doudeja,

Sinistro o clarāo seduz!

Mais se enovela a batalha,

Mais torvelinha e se espalha,

Toma a cometa Jesus.

Da raça de um mundo nôvo,

Tu fundaste a realeza!

Teus pobres braços cortados

Por êsse espaço espalhados

Mudos suplicam: - Saudade,

Leva-me às pátrias areias,

Quero quebrar as cadeias,

Pátria, pátria, liberdade!..."

E termina:

"Morres grande entre os gigantes,

Limpo, limpo de brasões,

Pequenino como dantes,

Ao retumbar dos canhōes!...

Silêncio... ninguém responde...

Não te fizeram visconde, 
Não tens um título ou medalha;

Mas ainda ao som da cometa

Dança à noite a baioneta

Pelos campos de batalha!

Tua glória vaga no ar,

É quase um sagrado mito;

O mármore pode quebrar,

Não dura sempre o granito,

Na solidão esquecido,

Pobre, sem túmulo, perdido,

Sem pedra, sinal ou cruz,

Tu simbolizas o povo,

Tu és quase um Cristo nôvo,

Tens o seu nome - Jesus!"

Basta quanto ao José Bonifácio poeta. Passemos ao professor.

\section{O PROFESSOR}

Formado em 1853, logo no ano seguinte, José Bonifácio foi nomeado lente substituto da Faculdade de Direito de Pernambuco. Permanecendo por pouco tempo em Olinda (1855-1858), por decreto de 5 de maio, veio transferido para São Paulo. Em 1861, foi nomeado lente catedrático de direito civil. Nessa ocasião, já era deputado por São Paulo.

Mais interessante, porém, que o acompanhar, passo a passo, na Faculdade, é tomá-lo no ano de 1868 e ceder a palavra a um de seus alunos.

Nessa ocasião, na política nacional, cumpre lembrar, o chamado Poder Moderador havia revelado toda a sua face ditatorial de Poder Fundador da vontade da nação. Em rápida apreciação histórica, pode-se dizer que o monarca, desde a maioridade antecipada, o famoso "Quero já" de 1840, até 1847, por sua pouca idade 14 anos em 1840 -, não poderia influir na composição do Ministério. Em seguida, a partir de 1847, quando se introduz verdadeiramente o parlamentarismo no Império, pela criação do cargo de presidente do Conselho de Ministros (Decreto n. 523, de 20 de julho de 1847), e até 1868, não são 
grandes as divergências entre liberais e conservadores. Data, porém, de então, da famosa crise de 68, a revelação da força brutal embutida no Poder Moderador, a tomada de consciência desse quadro institucional, e, pode-se dizer, data também daí o começo do fim da monarquia no Brasil.

Os fatos são os seguintes: o conflito que se arrastava entre, de um lado, o ministério liberal de Zacarias e, de outro, o chefe militar e líder conservador Caxias, encontra seu fim com a nomeação feita pelo monarca, para senador pelo Rio Grande do Norte, do conservador Salles Torres Homem, o exrebelde Zimandro. Zacarias, contrariado, se demite e D. Pedro II designa para formar o novo gabinete o ultraconservador Visconde de Itaboraí. É o mesmo que dirá: "o rei reina, governa e administra", em réplica à fórmula de Thiers, "o rei reina, mas não governa".

O novo Ministério, todo composto de conservadores, não tem absolutamente o apoio da Câmara. José Bonifácio, em célebre discurso, diz: "Hoje, do dia para a noite, um ministério cai no meio da numerosa maioria parlamentar $e$ inopinadamente surgem os novos ministros como hóspedes importunos que batem fora de horas e pedem agasalho em casa desconhecida". Propõe, então, desafiadoramente, a moção de desconfiança. A moção é aprovada por maioria esmagadora: 85 a 10 .

A solução, porém, não foi a queda do Ministério, e sim, a dissolução da Câmara. Ora, dissolvida a Câmara, o caminho para sair do impasse era nova eleição, mas nova eleição conduzida pelo governo e, portanto, com resultados previsíveis. Daí o célebre discurso de Nabuco de Araújo, o discurso do 'sorites', do raciocínio de proposições encadeadas: "Ora, dizei-me: não é isto uma farsa? Não é isto um verdadeiro absolutismo, no estado em que se acham as eleições em nosso país? Vedes este 'sorites' fatal, este 'sorites' que acaba com a existência do sistema representativo: o Poder Moderador pode chamar a quem quizer para organizar ministérios, esta pessoa faz a eleição, porque há de fazê-la; esta eleição faz a maioria. Eis, aí está o sistema representativo do nosso país!".

Em 1868, deu-se, pois, graças ao "estelionato" político e como disse, então, Saldanha Marinho -, a queda dos liberais. José Bonifácio, dissolvida a Câmara, volta a São Paulo e às aulas na Faculdade. É de um de seus alunos o depoimento que segue: 
"Discípulo, como fui, de José Bonifácio, seria ongulho, se nāo fosse gratidāo, vaidade, se nāo fora dever, dar-vos aqui testemunho do seu magistério. Foi em 1868, quando comecei a ouvi-lo. Vinha ele dessa memorável sessão parlamentar, em que a onipotência da coroa, por imperscrutável mistério de sua graça houve por bem, depois de Humaitá, vitimar à reabilitação de Timandro o partido de cujas simpatias populares o dinasta se valera para a campanha do Prata. Quando José Bonifácio assomou na tribuna, tive pela primeira vez a revelação viva da grandeza da ciência que abraçávamos. A modesta cadeira do professor transfigurava-se; uma espontaneidade esplendida como a natureza tropical borbulhava dali nos espíritos encantados; um sopro magnífico animava aquela inspiração caudal, incoercivel, que nos magnetizava de longe na admiração e no êxtase. Lembra-me que o primeiro assunto de seu curso foi 'a retroatividade das leis'. Nas suas preleçōes, que a hora interrompia sempre inopinada como dique importuno, a suma filosofia jurídica, a jurisprudência romana, os códigos modernos, a interpretação histórica, o direito pátrio passavam-nos pelos olhos translumbrados em quadros incomparáveis, inundados na mais ampla intuição científica, impelidos por uma dialética irresistivel. E uma memória miraculosa, uma dessas memórias capazes de reconstruir, como a de Scaligero, a 'Iliada' e a 'Odysséa', como a de Macaulay, 'O Paraíso Perdido', como a de Pascal, tudo o que ele tivesse lido uma vez, arrastava em catadupa leis, datas, fatos, brocardos, algarismos, idéias, fragmentos mínimos de minério precioso e enormes massas aluviaes de saber, que não se imagina como aquele 
Niagara pudesse carrear sem alteraçāo de sua majestade, nem prejuízo de sua limpidez."

Esse aluno, terceiranista de 1868, que tão generosamente elogia o mestre, é Rui Barbosa. Era seu colega de turma Castro Alves, que, então, deslumbrava com suas declamações as platéias paulistas e que, apesar de aluno, também se tornaria grande amigo de seu mestre José Bonifácio.

Quando, porém, os estudantes organizavam um banquete político em homenagem a José Bonifácio, na chamada Sala da Concórdia, em 13 de agosto de 1868, o escolhido para falar em nome de todos não é um nem outro. É um terceiro tão importante na história da cultura brasileira quanto os outros dois. Seria isto possível? Sim; quem falou foi Joaquim Nabuco, outro terceiranista de 1868.

Bem mais tarde, por ocasião da morte de José Bonifácio, Rui Barbosa assim relembra esse banquete:

"Entre as reminiscências do meu curso jurídico nesta cidade, nunca se me desfará da lembrança a recepção com que o acolheu, depois do golpe de estado de 16 de julho, a juventude acadêmica de 1868, em um banquete político de grandes proporções, que assinalou data na memória de quantos o celebramos; Joaquim Nabuco, o futuro orador do abolicionismo, ponto radiante que já se destacava na coroa solar do nome paterno; Barros Pimentel, merecimento dos mais puros, envolvido tenazmente pela sua modéstia em um casulo de seda; Martim Cabral, grande bólide fulgurante, que se perdeu no horizonte da tribuna brasileira; Gavião Peixoto, um dos testamenteiros moraes de José Bonifácio; Salvador de Mendonça, o publicista do Ypiranga; Americo de Campos, o estóico; Americo Brasiliense, temperamento americano alienado para a república pela rotina pervicaz da monarquia; $F$. de Menezes, um folhetim vivo, o boêmio da esperança, o fundador da 'Gazeta da Tarde'; Castro Alves, o poeta 
dos escravos. José Bonifácio teve ali palavras comovidas, que se fonografaram no espirito dos ouvintes: 'Os combatentes de hoje', dizia, 'são as aves já em meio do caminho, pisadas nos ramos secos da floresta. A mocidade é o futuro, as andorinhas em busca da primavera e da luz'. E Ferreira de Menezes de atalhar:

A luz é V.Excelência!. E comenta Rui Barbosa, em acréscimo: ' $E$ o foi até o derradeiro dia'"

Além de Joaquim Nabuco, Castro Alves e Rui Barbosa, cabe lembrar que eram também terceiranistas em 1868 dois futuros presidentes da República, Afonso Pena e Rodrigues Alves. Sentados lado a lado, na sala de aula, ouvindo o professor José Bonifácio: Joaquim Nabuco, Castro Alves, Rui Barbosa, Afonso Pena, Rodrigues Alves - momento alto da Faculdade de Direito!

De Castro Alves, que não era bom aluno, dizem que qualquer pequena explicação lhe permitia fazer boa figura. Rodrigues Alves fez a queixa que todo professor ouve: disse o paulista que, de certa feita, ensinou ao baiano toda a matéria da sabatina e, ao final, Castro Alves tirou boa nota e ele, a única nota sofrível de todo o curso!

Numa apreciação global sobre a atividade estritamente didática de José Bonifácio, diz Almeida Nogueira (vol. 2, p. 178):

"As preleções de José Bonifácio se revestiam de forma eloqüentíssima.

- Mesmo tratando de assuntos, tidos por pesados, ele sabia encantar, pela magia do seu verbo eloqüente. Tomou-se isto sensivel no terceiro ano (1864), a propósito do 'Cabeça de casal', e no quarto, a respeito da 'Posse'".

Mas, às vantagens da eloquência, acrescentavam-se alguns defeitos. Continua o mesmo autor: 
"Em primeiro lugar, tinha pouca assiduidade; depois, as suas preleções ressentiam-se, em demasia do estilo oratório, sacrificando, pelas galas da roupagem, a clareza da exposição e a inteligência da matéria.

Era freqüente a presença de assistentes, não acadêmicos, na aula de José Bonifácio. Compareciam, por vezes, pessoas qualificadas, por exemplo, desembargadores da Relação.

Nessas ocasióes, a sua palavra revestia-se de maior fulgor. Eram as preleçōes mais brilhantes, porém menos proveitosas para os alunos. Quando não havia na sala pessoas estranhas, tornava-se ele outro homem, menos orador, e mais professor".

Em 1870, mediante permuta, José Bonifácio passou a reger a cadeira de Direito Criminal. Jubilou-se em 1881.

Sempre muito amável no trato com os alunos, terminaremos esta parte da exposição, contando, ainda com Almeida Nogueira, um fato acadêmico, sobre o professor doublé de parlamentar. A história, se não chega a ser muito engraçada, revela bem o gosto pelo insólito e a generosidade do caráter de José Bonifácio.

Era amável e cavalheiro, no trato com os alunos; não se dispensava, entretanto, de os espichar desapiedadamente nos atos.

Argumentava por dilema, e, quando o adversário, preso, e já sem saída, se punha a estrebuchar... então José Bonifácio ria gostosamente, mas concluía com um:

\section{- "Tem dito bem; estou satisfeito."}

Ele raramente chamava os discípulos à lição, ou fazia sabatina.

Saindo uma vez desta regra, na aula do quarto ano, deu a palavra a um estudante, vindo de Pernambuco, e que para lá voltou no ano seguinte:

Este levantou-se... e surpreendeu assim a toda aula, supondo alguns que fosse sistema, na outra Faculdade, ficar-se em pé ao dar a lição.

político:

$\mathrm{O}$ caso, porém, era outro: pois o pernambucano deu um tiro 
- "Peço escusa a V.Ex., porque não me acho preparado"...

José Bonifácio, extremamente generoso, interrompeu-o de pronto:

- "Oh! meu colega, queira perdoar-me!... Eu não sabia... Falará noutra ocasiäo"..."

\section{O ORADOR PARLAMENTAR}

A vida parlamentar de José Bonifácio foi longa e brilhante; sai de 1860, quando foi eleito deputado à Assembléia Legislativa de São Paulo até sua morte em 1886. Foi eleito deputado provincial quatro vezes, deputado geral, também quatro, e proclamado senador, vitalício, em 1879. Foi Ministro da Marinha em 1862, no chamado "Ministério dos Anjinhos" porque durou somente 4 dias -, e Ministro do Império, em 1864. Em 1883, recusou a presidência do Conselho de Ministros.

Seus discursos sempre provocaram no Parlamento viva impressão. O ministro plenipotenciário dos Estados Unidos, Hillard, havendo assistido ao debate sobre a eleição direta, em 28 de abril de 1879, escreveu ao Departamento de Estado que ouviu todo o discurso da tribuna diplomática e ficou profundamente emocionado. "Nunca assisti a nada que de longe se aproximasse de oração como essa em um recinto parlamentar".

E termina assim seu despacho: "a Câmara estava repleta e uma compacta multidão comprimia-se nas vastas galerias. Quando ele se levantou, um silêncio profundo invadiu o auditório. José Bonifácio dispōe realmente de todos os requisitos que se possam exigir de um orador do mais alto estilo. Sua formação é liberal, tem a prática forense, professor na Faculdade de Direito de São Paulo, sua probidade pessoal é inatacável".

Depois de referir-se à bela presença do orador, à sincera exaltação que mostrava, diz como, em dado momento, foi preciso levantar a sessão devido ao tumulto no plenário e nas galerias provocado pelo entusiasmo estrepitoso dos ouvintes. No final, um verdadeiro delírio apoderou-se de toda a gente, e os aplausos incessantes prolongaram-se por longo tempo. À saída, o diplomata ainda viu José Bonifácio cercado de imensa massa popular. Todos o acompanhavam entre aclamações ininterruptas até a estação das lanchas, onde ia 
embarcar para sua casa, do outro lado da baía. No momento de partir, Hillard viu-o tirar o chapéu, voltar-se para a multidão e agradecer as demonstrações de repulsa a um projeto que queria cercear o direito do sufrágio.

Longe, porém, da presença do orador, a verdade é que a leitura de seus discursos não empolga. Tem razão seu antigo aluno e, depois, companheiro de partido liberal, Joaquim Nabuco, quando se prende antes à nobreza de seu caráter, à sua dignidade, à beleza de sua vida e à sua capacidade de renúncia, que à sua oratória escrita.

O que mais impressiona na trajetória política de José Bonifácio é o fato de que, sempre, entre duas opções, escolheu a mais generosa. Foi a favor do alargamento do voto, lutando pela manutenção do voto do analfabeto (infelizmente, suprimido em 1879); da disseminação do ensino; da autonomia dos municípios; da moralização da Justiça, então infamada pelas cumplicidades partidárias; da liberdade administrativa das províncias; da liberdade do trabalho; e, principalmente, da causa que lhe tomou totalmente os últimos anos de vida, da abolição da escravidão.

Acompanhá-lo em toda a sua laboriosa vida parlamentar, exigiria um mergulho profundo na história do Segundo Império, impossível de fazer, por falta de tempo, neste momento. Passemos, pois, diretamente a seus últimos anos, caracterizados pela frase: "Primeiro a abolição. Nada sem a abolição, tudo pela abolição".

\section{JOSÉ BONIFÁCIO E A ABOLIÇÃO}

Com a dissolução da Câmara em 1868, a derrubada dos liberais foi total. Ninguém foi poupado: funcionários públicos e juízes de direito foram demitidos. José Bonifácio, de volta a São Paulo e às aulas, abriu escritório de advocacia com a colaboração do primo Antonio Carlos e do dr. José Maria de Andrade, demitido do cargo de inspetor do Tesouro.

O grande abolicionista negro, Luís Gama, simples escrivão da Secretaria de Polícia, foi também demitido. Torna-se, então, amigo constante de José Bonifácio, cuja casa freqüenta todos os dias e a quem trata carinhosamente de Mister Jose. Já se conheciam - certamente desde 1861, quando na segunda edição das Trovas burlescas de Getulino, apareceram algumas poesias de José 
Bonifácio mas é a partir daí que através de intensa atividade judicial, passam ambos a tentar obter, por todos os meios legais, a libertação dos escravos.

Luís Gama era baiano e a história de sua infância é de tal tristeza, que é de espantar que não seja mais conhecida; nem Ésquilo ou Sófocles puderam imaginar tamanha tragédia. Luís Gama era filho de africana livre, de nação nagô, Luiza Mahin, dizem todos que belíssima: pele escura acetinada, dentes brancos, corpo bem-feito, não muito alta, conhecida na Bahia inteira, por cujas ruas passava vendendo quitutes. Com o tabuleiro equilibrado sobre a cabeça, o chale da Costa nos ombros, andar sensual, Luiza Mahin tinha personalidade forte e temperamento briguento. Em 1837, participou da revolução denominada Sabinada; foi presa e enviada para o Rio.

Luís Gama, que sempre manteve grande admiração pela mãe, tinha então 7 anos. Seu pai era branco, de origem portuguesa, "fidalgo de uma das principais familias baianas". Parece que, durante os primeiros anos do menino, não foi mau pai. Era apaixonado pela caça e pela pesca; gostava de bons cavalos; "jogava bem as armas e melhor as cartas; comprazia-se em folguedos e orgias; esbanjou uma boa herança, havida de uma tia em 1836". Em 1840, está sem dinheiro.

Num domingo, 10 de novembro, aparece na casa da mulher que então tomava conta do menino; pede que o arrume para darem um passeio. E lá vai Luís Gama, de camisa branca, gorro na cabeça, com o pai até o cais; aí, o pai chama um barco a remo, a pretexto de que precisa falar com o comandante do navio Saraiva para acertar um negócio.

O navio era uma embarcação de dois mastros, um patacho, e estava carregado de escravos que eram levados da Bahia para o Rio e São Paulo, onde havia grande necessidade de braços para o nascente ciclo do café.

Chegados ao tombadilho, conversaram com o comandante do navio. Em seguida, o pai, sorrateiro, sai procurando escapar às vistas do filho. $\mathrm{O}$ menino, esperto, logo vê o pai entrando no bote; dá-se conta da situação e berra, apavorado: "- Papai, o senhor me vendeu!"

Não houve resposta. $\mathrm{O}$ único som foi o barulho dos remos na água azul da Bahia. 
Vendido! E lá se foi o menino de 10 anos, escravizado, para o sul. Passa muitos sofrimentos. Em 1847, com 17 anos, ainda escravo, está morando aqui perto, no Largo da Misericórdia, entre a rua Direita e a Quintino Bocaiúva. Começam então suas relações com a Faculdade: um estudante de direito Antonio Rodrigues de Araújo, futuro juiz, vem morar na casa de seu dono e o ensina a ler, escrever e contar. No ano seguinte (1848), Luís Gama obtém as provas de que nascera livre e escapa à escravidão.

Mais tarde, é ordenança do Conselheiro Furtado, o professor de quem recebe lições de direito, que muito o ajudarão. Passa em seguida a advogar como rábula. A partir de 1868, como disse, trabalha com José Bonifácio, na libertação dos escravos. Dizem que Luís Gama obteve mais de 500 libertações no Forum (100 somente no inventário de Manoel Joaquim Ferreira Neto).

Nos anos seguintes, a Faculdade vive inteiramente o clima da abolição. Alunos e professores - José Bonifácio à frente - desfechavam diariamente golpes decisivos na inumana instituição.

O estudante Antonio Bento promovia o êxodo em massa dos escravos.

Fazia-os saírem todos ao mesmo tempo das fazendas, mas em paz, em ordem, às vezes na presença e sob as vistas do próprio senhor. Este nada podia fazer para obstar a partida de todos os seus escravos, porque não dispunha de força material suficiente para esse fim, nem podia requisitar a intervenção da força pública, uma vez que, segundo tese jurídica sustentada por professores e juízes, não havia desordem a reprimir, nem a mínima perturbação da tranqüilidade pública. A saída em massa não era fácil.

Escreve Almeida Nogueira:

"Que esforço para convencer os pobres negros de que nāo era crime a fugida, e crime, sim, a escravidāo!"

E continua:

"Que cenas patéticas se desenrolavam entāo nesta cidade! Viam-se a desembarcar à noitinha dos trens do interior turmas $e$ turmas de homens, mulheres $e$ crianças de cor, que fugiam das fazendas. Chegavam a 
S.Paulo e logo se encaminhavam para a casa de Antonio Bento, à nua da Liberdade, entre o Largo Sete de Setembro e o da Liberdade, antigo do Pelourinho. Transitavam pelas nuas, a sobraçarem pequena trouxa de roupa, quietos, mansos, humildes, dir-se-ia, mesmo, que corridos e envergonhados de estarem fugindo à escravidão."

Terminemos relatando o debate inaudito de José Bonifácio com o Ministro da Justiça poucas semanas antes de morrer. Tinha havido o trucidamento de quatro escravos no município de Paraíba do Sul, a poucas horas da Corte. Joaquim Nabuco denunciou o fato na imprensa e o senador Dantas formulou o seguinte requerimento de informação:

"Requeiro que pelo Ministério da Justiça se informe se depois de açoitados quatro escravos do Sr. Caetano do Vale, na Paraíba do Sul, foram mandados a pé para a fazenda; outrossim, se dois desses escravos foram vistos mortos na estação de Três Rios e dois outros seguiram moribundos em um carro de bois para o seu destino; finalmente, qual o número de açoites aplicados a cada um diariamente, se estava presente ao castigo algum facultativo, que autorizasse a aplicação de 300 açoites de uma vez em cada um dos pacientes. Paço do Senado, 30 de julho de 1886. (a) Dantas."

Em 11 de agosto exatamente 11 de agosto - de 1886, trava-se o inaudito debate de José Bonifácio e o Ministro da Justiça.

"O senador José Bonifácio: - $A$ narrativa é simples, mas cheia de interrogações. Os escravos são condenados à pena de 300 açoites e recebem 1.500, por um processo especial de multiplicações generosas; o máximo de 50 açoites por dia, segundo os estilos da justiça, que, por serem velhos, não podem ser alterados, eleva-se a 150. Fantasio as cenas que deviam ter precedido o desfecho daquele drama infeliz! Executada a pena, os escravos sāo entregues a um preposto de seu senhor; naturalmente amarrados, caminham a pé para o seu destino; devia ser a fazenda 
de seu dono, e foi apenas a sepultura deserta do caminho. Até gordos e felizes (ninguém tinha perguntado por isso), saíram das māos da Justiça e morrem de súbito... e não é um só... sāo dois, no mesmo lugar e quase na mesma hora, como se uma causa comum atuasse sobre aqueles organismos torturados. Os corpos inanimados, e talvez ainda com os vergões do azorrague judiciário, voltam para a estação próxima, exibindo na terra as nossas misérias, e pedindo talvez no desamparo e na solidão às claridades do dia as misericórdias de cima. O nobre Ministro pode dizer-nos se não há criminosos ou responsáveis?

O ministro da Justiça: - Já se está fazendo o processo.

O senador José Bonifácio: O primeiro dever, desde que a morte verificou-se nas condiçōes expostas; o primeiro dever da autoridade era ordenar a autópsia, recolhendo desde logo tudo o que pudesse constituir o corpo de um delito possível. O ministro da Justiça: Fez-se a autópsia.

O senador José Bonifácio: No telegrama que $V$. Exa. leu não se falava em autópsia, e sim em exame...

O ministro da Justiça: - Mas recebi depois comunicação do delegado de polícia.

O senador Dantas: Fez-se a autópsia, depois de exumados?

O senador Silveira da Motta: $O$ que se diz que se fez, foi o exame.

O ministro da Justiça: Fez-se a autópsia.

O senador José Bonifácio: - Os escravos, depois de entregues ao preposto de seu dono, morreram em caminho, e os seus corpos foram trazidos para a estação próxima. $O$ que se pretende saber é se se fez a autópsia nessa ocasião, porque é fato essencial que não podia ser esquecido pelos telegramas, e a mesma afirmativa do exame parece excluir a existência da autópsia.

O ministro da Justiça: - Fez-se.

O senador José Bonifácio: Na estação?

O ministro da Justiça: - Sim, senhor.

O senador José Bonifácio: O sr. taquígrafo tome nota desta declaração.

O senador José Bonifácio: - Pode V. Exa. informar-me de que morreram os escravos?

O ministro da Justiça: - De congestão pulmonar (Risos).

O sr. Presidente: - Atenção!

O senador José Bonifácio: - Os escravos morrem quando estavam no gozo de plena saúde, morrem de súbito em caminho, morrem logo depois de entregues nas 
mäos de seu condutor, morrem dois, como se houvesse ajuste entre ambos, morrem fulminados quase ao mesmo tempo, no mesmo caminho e dando os mesmos passos, amarrados um e outro depois de terem sido oportunamente açoitados com a permissão do médico...

O ministro da Justiça: - Com a presença.

O senador José Bonifácio: - A assistência do médico importa a permissão do castigo infligido; não façamos questāo de palavras. Se não há motivo para a soberba, não há motivo para o desconsolo. A morte verificou-se com todos os sacramentos legais; não faltou mesmo a graça divina da multiplicação do azorrague. Ora, o que têm os magistrados com isso, executores ou nāo executores da sentença? Hāo de entreter-se em alterar a forma do instrumento do suplício, com ofensas das velhas usanças?!!

- A lei criminal tomou para medir o castigo uma unidade, e graduou o máximo dos açoites por dia, presumindo bem ou mal que não devia ou não podia elevá-los além de 50; a pena de açoites não é a pena de morte; mas tudo isso o que importa? Desde que o cabo do chicote é um só, podem aumentar o número dos açoites, porque a aritmética da escravidão é essa mesma: um pode ser igual a 4, a 5 e 6 ...

- No entanto, se não foi consultado o médico; se, qualquer a forma do instrumento do martíio, a pena graduou-se a capricho; se a morte pode de qualquer modo filiar-se ao excesso de execução; se fatos posteriores, e pelos quais não responde a Justiça, dão os motivos do inesperado falecimento, há ou não há responsáveis perante a lei criminal?"

Poucos dias depois, terminada a sessão parlamentar, José Bonifácio volta a São Paulo. A viagem de trem, do Rio a São Paulo, não era fácil naquele tempo: não havia hora para chegar e o trem vinha com as janelas fechadas por causa do pó.

Chega, em 26 de outubro; em casa, à noite, após jantar com os filhos, filhas e genros vem a falecer de madrugada, de colapso cardíaco.

Eis aí José Bonifácio o Moço. "José", nome bíblico, que significa "o que acrescenta". "Bonifácio", nome latino que significa "o que faz o bem". E "moço", palavra portuguesa que significa "jovem". O nome corresponde à pessoa.

$\mathrm{E}$ a pessoa corresponde à sua e à nossa Faculdade de Direito. 